Morson, B.D. \& Dukes, C.E. (Ed.) (1960) Cancer of the Rectum, Vol. 3, p. 92. E. and S. Livingstone, London and Edinburgh.

Mowat, J. \& Miller, D. (1973) Intestinal obstruction by uterine fibroids. Journal of the Royal College of Surgeons of Edinburgh, 18, 237.

Neuman, Z. (1952) Leiomyosarcoma of the rectum, developing from benign leiomyoma. Annals of Surgery, 135, 426.

Novak, E. \& ANDERSON, D.F. (1937) Sarcoma of the uterus. American Journal of Obstetrics and Gynecology, 34, 740.

SilverberG, S.G. (1971) Leiomyosarcoma of the uterus. Obstetrics and Gynecology, 38, 613.
Skandalakis, J.E., Gray, S.W., Shepherd, D. \& Bourne, G.H. (1962) Smooth Muscle Tumours of the Alimentary Tract; Leiomyomas and Leiomyosarcomas-A Review of 2,525 cases. pp. 98, 135, 203, 204. Charles C. Thomas, Springfield, Illinois.

SpIRo, R.H. \& Koss, L.G. (1965) Myosarcoma of the uterus. Cancer. Philadelphia, 18, 571.

StaRR, G.F. \& DockerTy, M.B. (1955) Leiomyomas and leiomyosarcomas of the small intestine. Cancer. Philadelphia, 8, 101 .

Stearns, H.C. \& Sneeden, V.C. (1966) Leiomyosarcoma of the uterus. American Journal of Obstetrics and Gynecology, 95, 374.

TAYLOR, H.B. \& NORRIS, H.J. (1966) Mesenchymal tumours of the uterus, IV. Diagnosis and prognosis of leiomyosarcomas. Archives of Pathology, 82, 40.

\title{
Staphylococcal septicaemia with disseminated intravascular coagulation associated with acupuncture
}

\author{
ELIZABETH IZATT \\ M.B., Ch.B., M.R.C.P.
}

\author{
MARTIN FAIRMAN \\ M.B., M.R.C.P.
}

\section{Department of Medicine, The General Infirmary at Leeds}

\section{Summary}

A case of disseminated intravascular coagulation due to staphylococcal septicaemia is described in which the source of infection was likely to have been acupuncture therapy.

\section{Introduction}

The ancient oriental art of acupuncture has recently enjoyed a revival of popularity. Whatever the merits of this form of treatment, complications are occasionally reported including serum hepatitis (Hussain, 1974), pneumothorax (Carron, Epstein and Grand, 1974) and renal disease (Keller, Parker and Garvin, 1972). A further hazard is illustrated by the case reported here.

\section{Case report}

A previously fit 66-year-old man was admitted with a 2-day history of malaise and fever. Two days before the onset of symptoms he had undergone acupuncture treatment around the knees for longstanding osteoarthritis. During the night before admission he was found on the floor of his bedroom confused and rambling. Examination showed him to be pyrexial $\left(38.5^{\circ} \mathrm{C}\right)$, drowsy and disorientated, but

Correspondence: Dr Martin Fairman, University of Cincinnati Medical Center, College of Medicine, 231 Bethesda Avenue, Cincinnati, Ohio 45267, U.S.A. there were no localizing neurological signs. A soft ejection type systolic murmur was heard over the aortic valve. The skin, nails and abdomen were unremarkable. During the next 2 days his level of consciousness diminished and he developed mild generalized rigidity with extensor plantar responses. Several septic foci appeared in the skin together with widespread purpura and pyoarthroses of the left elbow and wrist.

Investigations on admission showed normal urine, blood film, haemoglobin, white cell and platelet count. Lumbar puncture yielded clear CSF under normal pressure containing 10 polymorphs, 40 $\mathrm{RBCs} / \mathrm{ml}$, and $0.53 \mathrm{~g} / 1$ protein. Bilateral carotid arteriograms excluded intracerebral abscess or subdural haematoma. Eight blood cultures yielded growths of Staphylococcus aureus after $48 \mathrm{hr}$ incubation. By the third hospital day, the haemoglobin had fallen to $9 \cdot 3 \mathrm{~g} / \mathrm{dl}$ and the platelet count to $34 \times 10^{9} / 1$. During this time the blood film showed a progressive shift of the white cells to the left, with the emergence of crenated $(70 \%)$, distorted or fragmented red cells. Plasma fibrin degradation products rose from 16 $\mathrm{mg} / \mathrm{l}$ to $64 \mathrm{mg} / \mathrm{l}$ (normal range $<10 \mathrm{mg} / \mathrm{l}$ ). The blood urea rose to a peak of $34 \mathrm{mmol} / \mathrm{l}$. $\mathrm{Hb} \mathrm{sg}$ was negative and immunoglobulins normal. Other investigations were non-contributory.

Treatment was started on the third hospital day 
with ampicillin, cloxacillin and a brief course of dexamethasone. Clinical response was rapid, and within $72 \mathrm{hr}$ the patient was alert, orientated and obviously recovering. The antibiotic was changed on bacteriological advice to methicillin and continued for 6 weeks. After the prompt resolution of pyrexia, fibrin degradation product levels returned to normal, along with the urea, haemoglobin and platelet values. The blood film was normal within 5 days of starting treatment. Three months later the patient remains well, although still troubled by painful knees.

\section{Discussion}

Recovery from disseminated intravascular coagulation is unusual, although less so when, as in the present case, a treatable cause can be identified.
Although in many instances of staphylococcal septicaemia no cause is apparent, it is suggested that in this case the introduction of infection occurred during acupuncture.

\section{Acknowledgment}

We wish to thank Dr Clive Hayter for permission to publish clinical details.

\section{References}

Carron, H., Epstein, B.S. \& Grand, B. (1974) Complications of acupuncture. Journal of the American Medical Association, 228, 1552.

HussaiN, K.K. (1974) Serum hepatitis associated with repeated acupuncture. British Medical Journal, 3, 41.

Keller, W.J., Parker, S.G. \& Garvin, J.P. (1972) Possible renal complications of acupuncture. Journal of the American Medical Association, 222, 1559. 